Izabela Krzeptowska-Moszkowicz

ORCID 0000-0002-5035-1832

Instytut Architektury Krajobrazu, Politechnika Krakowska (Kraków, Polska)

ikrzepto@.pk.edu.pl

\title{
Zainteresowanie ochroną przyrody i historią botaniki w Polsce oraz pasja popularyzacji wiedzy przyrodniczej w twórczości Seweryna Józefa Krzemieniewskiego (1871-1945)
}

\begin{abstract}
Abstrakt
Celem pracy jest przedstawienie sylwetki Seweryna Józefa Krzemieniewskiego, jednego z pionierów polskiej mikrobiologii, jako uczonego o zainteresowaniach humanistycznych i interdyscyplinarnych. Jego twórczość w tym obszarze objęła przede wszystkim historię botaniki wniosła ważny wkład w rozwój tej dyscypliny w Polsce, w okresie międzywojennym. Krzemieniewski jest autorem prac analizujących badania przyrodnicze misjonarza Michała Boyma, a także artykułu
\end{abstract}

\begin{tabular}{|c|c|c|c|c|c|}
\hline \multicolumn{2}{|c|}{$\begin{array}{l}\text { INFORMACJA } \\
\text { O PUBLIKACJI }\end{array}$} & $\begin{array}{l}\text { Ptudia } \\
\text { Pistoriae } \\
\text { cientiarum }\end{array}$ & $\begin{array}{r}\text { e-ISSN 2543-702X } \\
\text { ISSN 2451-3202 }\end{array}$ & 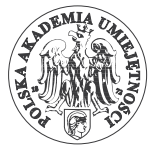 & $\begin{array}{l}\text { } \\
\text { BRYLANTOWY MODEL } \\
\text { OTWARTEGO DOSTĘPU }\end{array}$ \\
\hline \multicolumn{6}{|c|}{$\begin{array}{l}\text { CYTOWANIE } \\
\text { Krzeptowska-Moszkowicz, Izabela 2020: Zainteresowanie ochroną przyrody i historią botaniki oraz pasja } \\
\text { popularyzacji wiedzy przyrodniczej w twórczości Seweryna Józefa Krzemieniewskiego (1871-1945). } \\
\text { Studia Historiae Scientiarum 19, ss. 53-74. DOI: } \underline{10.4467 / 2543702 X S H S .20 .004 .12560} \text {. }\end{array}$} \\
\hline \multicolumn{3}{|c|}{$\begin{array}{l}\text { OTRZYMANO: } 23.11 .2019 \\
\text { ZAAKCEPTOWANO: } 22.08 .2020 \\
\text { OPUBLIKOWANO ONLINE: } 30.09 .2020\end{array}$} & $\begin{array}{c}\text { POLITYKA } \\
\text { ARCHIWIZOWANIA } \\
\text { Green SHERPA / } \\
\text { RoMEO Colour }\end{array}$ & (c) & $\begin{array}{l}\text { Similarity Check } \\
\text { Powered by ithenticate }\end{array}$ \\
\hline WWW & \multicolumn{5}{|c|}{ https://ojs.ejournals.eu/SHS/; http://pau.krakow.pl/Studia-Historiae-Scientiarum/archiwum } \\
\hline
\end{tabular}


przedstawiającego historię botaniki w ośrodku lwowskim. Opracował również biogramy botaników polskich, nie wszystkie jednak zostały wydane drukiem. Ponadto uczony przez kilka lat angażował się w intensywne prace na rzecz ochrony przyrody, co pozwala zaliczyć go w tym okresie do grupy czołowych działaczy na tym polu w Polsce i wpisuje na karty historii ochrony przyrody.

U podstaw humanistycznej działalności Krzemieniewskiego wydaje się leżeć jego przekonanie o podstawowym znaczeniu edukacji dla rozwoju świadomego i wrażliwego przyrodniczo społeczeństwa, co znajduje wyraźne odbicie w opublikowanych przez niego pracach. Ta idea ma również odzwierciedlenie w działaniach uczonego jako popularyzatora wiedzy przyrodniczej oraz wykładowcy.

Słowa kluczowe: Seweryn Józef Krzemieniewski, historia botaniki, biogramy botaników polskich, historia ochrony prayrody w Polsce, edukacja prazyrodnicza, popularyzacja wiedzy prayrodniczej

\title{
Study of the interest of Seweryn Józef Krzemieniewski (1871-1945) in the nature conservation, the history of botany in Poland, and his passion for popularizing the natural sciences
}

\begin{abstract}
The aim of this paper is to present one of the pioneers of Polish microbiology, Seweryn Józef Krzemieniewski, as a scholar with humanistic and interdisciplinary interests. His work covered primarily the history of botany and was an important contribution to the development of this discipline in the interwar period in Poland. Krzemieniewski is the author of works analyzing the research of Michał Boym, a missionary in China, as well as of an article presenting the history of botany in Lviv. He also prepared biographies of Polish botanists, but not all of them werepublished. Additionally, the scientist was involved for several years in intensive work in nature conservation, which makes it possible to include him in the group of leading activists in this field in Poland of that period.
\end{abstract}


Krzemieniewski's belief in the fundamental importance of education for the development of conscious and environmentally sensitive society seems to be at the root of his humanistic activities, which is clearly visible in his published works. This idea is also reflected in his activities as a popularizer of natural science and a lecturer.

Keywords: Seweryn Józef Krzemieniewski, history of botany, biographies of Polish botanists, history of nature conservaton in Poland, natural science education, promotion of natural science

\section{Wprowadzenie ${ }^{1}$}

Seweryn Józef Krzemieniewski (1871-1945)² był botanikiem, którego główny nurt działalności naukowej koncentrował się na mikrobiologii, rozwijającej się w ówczesnym czasie w obrębie fizjologii roślin. Wywodził się on z krakowskiej szkoły naukowej Emila Godlewskiego sen. (1847-1930)3 ${ }^{3}$, z której wyszło wielu późniejszych profesorów wyższych uczelni ${ }^{4}$. Krzemieniewski był uciekinierem z zaboru rosyjskiego. Jako student Cesarskiego Uniwersytetu Warszawskiego (w 1. 1890-1894) trafił w roku 1894 na kilka miesięcy do więzienia za nielegalną działalność przeciw zaborcy, a mając być powtórnie aresztowanym zbiegł w 1895 r. do Krakowa, gdzie postanowił kontynuować przerwane studia.

1 Artykuł rozwija tezy przedstawione w referacie wygłoszonym podczas konferencji: „Humanistyczne pasje polskich przyrodników XIX-XX w.” (16 października 2015, Kraków, Komisja Historii Nauki PAU - Komitet Historii Nauki i Techniki PAN).

${ }^{2}$ Wśród publikacji poświęconych S. Krzemieniewskiemu są m.in. prace: Badura 1969; Hryniewiecki 1948; Rakoczy 2000.

3 Emil Godlewski sen. - fizjolog roślin, chemik rolny; studiował w Szkole Głównej w Warszawie, a dokształcał się w pracowniach E. Strasburger na Uniwersytecie w Jenie i J. Sachsa na Uniwersytecie w Würzburgu. Habilitował się na UJ w 1873 r. i został pierwszym docentem fizjologii roślin na ziemiach polskich. Prof. w Krajowej Wyższej Szkole Rolniczej w Dublanach, a następnie prof. w Studium Rolniczym UJ i jego długoletni dyrektor. Był współtwórcą (wraz z E. Janczewskim) tego Studium. Pod koniec życia (1920-1928) kierownik działu rolnego PINGW w Puławach. Badacz wielu procesów fizjologicznych. Ojciec dwóch uczonych: Emila Godlewskiego jun. (1875-1944) - prof. embriologii i biologii na Wyd. Lekarskim UJ, senatora, komisarza do walki z epidemiami w 1920 r., oraz Tadeusza Godlewskiego (1878-1921) prof. fizyki na Politechnice Lwowskiej, rektora tej uczelni, badacza zjawisk promieniotwórczych - zob. Krzeptowska-Moszkowicz 2013, ss. 273.

${ }^{4}$ Krzeptowska-Moszkowicz 2013, ss. 221-232. 
Już podczas nich zwrócił na siebie uwage prof. Godlewskiego, gdyż przed ich zakończeniem (1899-1900) został zatrudniony na stanowisku demonstratora w katedrze chemii rolnej w Studium Rolniczym Uniwersytetu Jagiellońskiego ${ }^{5}$. Kraków w tym czasie cieszył się dużą autonomia, przybywała tutaj elita intelektualna ze wszystkich zaborów, powstawały dzieła sztuki, literatury i nauki, a repolonizacja Uniwersytetu Jagiellońskiego spowodowała, że doszło do największego rozkwitu uczelni od czasów renesansu ${ }^{6}$. Botanika również przeżywała czasy świetności, a oprócz E. Godlewskiego sen. na innych krakowskich katedrach botanicznych zasiadali równie znakomici uczeni - Józef Rostafiński $i^{7}$ (1850-1928) czy Edward Janczewski ${ }^{8}$ (1846-1918). Byli to czołowi botanicy, pionierzy różnych dziedzin w obrębie botaniki, twórcy własnych szkół naukowych, prowadzący wraz z uczniami intensywne prace badawcze?

Badania S. Krzemieniewskiego z zakresu mikrobiologii, które rozpoczął w Krakowie, w niezwykłej atmosferze naukowej, a którym poświęcił dalsze lata pracy będąc profesorem w Akademii Rolniczej w Dublanach pod Lwowem, a następnie na Uniwersytecie Lwowskim, polegały na typowej pracy laboratoryjnej. Wymagała ona umiejętności prowadzenia żmudnych analiz, wyciagania precyzyjnych wniosków i ścisłej metodyki badawczej. Wyniki prac naukowych Krzemieniewskiego, często pionierskich, wykonanych indywidualnie lub wspólnie

${ }^{5}$ Hryniewiecki 1948, ss. 285-286.

6 Badura 1969, ss. 9-21.

7 Józef Rostafiński - botanik, historyk nauk przyrodniczych; studiował w Warszawskiej Szkole Głównej oraz na Uniwersytecie w Jenie, Halle i Strasburgu. Asystent A. de Bary'ego na Uniwersytecie w Strasburgu, gdzie w 1875 r. został docentem. Od 1878 r. profesor na katedrze botaniki UJ i dyrektor Ogrodu Botanicznego UJ. Zajmował się badaniami glonów, śluzowców oraz roślin naczyniowych. Prowadził szerokie studia nad historią nauk przyrodniczych. Był popularyzatorem nauk biologicznych zob. Zemanek 2000a, ss. 340 .

${ }^{8}$ Edward Janczewski - botanik; studiował w Krakowie i Petersburgu, a uzupełniał studia w Halle pod kierunkiem A. de Bary'ego. W 1873 r. habilitował się w UJ w Krakowie. Od 1875 r. był profesorem katedry anatomii i fizjologii roślin na Wydziale Filozoficznym UJ. Współtwórca Studium Rolniczego UJ. Jeden z założycieli Towarzystwa Ogrodniczego w Krakowie i jego długoletni prezes. Prowadził badania między innymi z zakresu anatomii roślin, genetyki, systematyki oraz ogrodnictwa zob. Majewski 2000, ss. 75-82.

9 Zemanek 2000b, ss. 46-48. 
z żoną Heleną Krzemieniewska (1878-1966) ${ }^{10}$ (nad bakteriami z rodzaju Azotobacter oraz miksobakteriami), a później także razem z uczniami, przyniosły mu duże uznanie $\mathrm{w}$ świecie nauki ${ }^{11}$. Poza tym zasadniczym kierunkiem badawczym charakterystycznym dla umysłu ścisłego, uwaga badacza kierowała się również w stronę problemów humanistycznych $\mathrm{i}$ interdyscyplinarnych. Uczony jest autorem prac z zakresu historii botaniki, ponadto zajmował się popularyzacją idei związanych z ochroną przyrody, a także upowszechnianiem problemów i odkryć naukowych zarówno ze swojej dyscypliny badawczej, jak i dziedzin pokrewnych.

\section{Badacz w dziedzinie historii botaniki}

Zainteresowania interdyscyplinarne S. Krzemieniewskiego dotyczyły w dużej części historii botaniki. Prace powstawały w końcowym okresie działalności uczonego, w latach 30. XX w. W tym czasie polska historia botaniki dopiero zaczynała rozkwitać i niewielu było uczonych posiadających bogaty dorobek w tym zakresie. Za jej twórcę na ziemiach polskich jest uważany Józef Rostafiński. W drugiej połowie XIX w. porzucił on wcześniejsze botaniczne zainteresowania naukowe i zają się wyłącznie studiami historycznymi, a dzieje botaniki rozważał na szerokim tle historycznym i kulturowym, w powiązaniu także $z$ innymi gałęziami nauki. Do najbardziej znaczących jego prac należą opracowania dotyczące wiedzy przyrodniczej w czasach średniowiecza i renesansu. Największym kontynuatorem działalności Rostafińskiego w obrębie tej specjalności naukowej był Bolesław Hryniewiecki (1875-1963), profesor Uniwersytetu Warszawskiego. Jest autorem pierwszego polskiego podręcznika historii botaniki (1949) oraz wielu innych publikacji z tego zakresu ${ }^{12}$. Krzemieniewski miał możliwość poznać obu uczonych, a także znał ich dorobek naukowy, który mógł być inspiracją do jego własnych prac.

${ }^{10}$ Helena Krzemieniewska - botanik, mikrobiolog; studiowała na UJ, będąc jedną z pierwszych studentek. Jako uczennica E. Godlewskiego sen. specjalizowała się w fizjologii roślin, później w mikrobiologii. Przez wiele lat współpracowała naukowo z mężem. Doktoryzowała się w 1945 r. na UJ. Profesor fizjologii roślin Uniwersytetu Wrocławskiego, w latach 1955-1960 prof. w Instytucie Botaniki PAN - zob. Brzozowski 1987, s. 305.

${ }_{11}$ Rakoczy 2000, ss. 155-164.

12 Zemanek 1992, ss. 31-45. 
Oprócz znaczącej działalności wymienionych badaczy, publikacje z zakresu historii botaniki były wydawane także przez innych uczonych, zwłaszcza już po odzyskaniu przez Polskę niepodległości. Przeważnie jednak powstawały pojedyncze prace poszczególnych autorów. Koncentrowano się w nich zarówno na analizie dokonań polskich uczonych, jak i na dziejach poszczególnych dziedzin botaniki, czy historii polskich ośrodków zajmujących się nauką o roślinach. Dużą część publikacji stanowiły nekrologi uczonych ${ }^{13}$. Twórczość S. Krzemieniewskiego w tej dziedzinie, obejmująca zarówno opracowania opublikowane, jak i takie, które nie zostały wydane drukiem, wydaje się więc istotna i to zarówno, jeśli wziąć pod uwagę liczbę prac, jak i ich treść. Badacz podchodził krytycznie do przedstawianych zagadnień, jego opracowania opieraja się na materiałach historycznych, a w przypadku biogramów zawieraja także osobiste wspomnienia. Jego dorobek publikacyjny $z$ tej dziedziny obejmuje przynajmniej dziesięć pozycji.

Ważne miejsce wśród publikacji z historii botaniki autorstwa S. Krzemieniewskiego zajmują artykuły poświęcone pochodzącemu ze Lwowa polskiemu misjonarzowi przyrodnikowi Michałowi Boymowi (16121659). Podczas swoich misyjnych podróży po Chinach zakonnik zebrał wiele cennych i nowych wiadomości z różnych dziedzin, między innymi także z zakresu nauk przyrodniczych. Krzemieniewski opublikował dwa artykuły poświęcone Boymowi, które ukazały się w czasopiśmie Kosmos. Pierwsza pracę pt. „Michał Boym jako botanik” wydał w 1934 r., opisując szeroko życie jezuity oraz koncentrując się na jego znanym dziele pt. Flora Sinensis (1656), przedstawiającym niektóre rośliny użytkowe Chin ${ }^{14}$. Monografia misjonarza jest do dziś rzadkością, a w ówczesnym czasie w zbiorach polskich były tylko dwa jej egzemplarze, w tym tylko jeden z kolorowymi rycinami w Bibliotece Uniwersyteckiej Uniwersytetu Jana Kazimierza we Lwowie, z którego korzystał uczony ${ }^{15}$. Krzemieniewski przeanalizował pracę pod względem botanicznym. Na podstawie opisów, ilustracji oraz podanych potocznych nazw ${ }^{16}$

${ }^{13}$ Niekiedy były to zbiorowe opracowania - jedna z najwcześniejszych zespołowych prac z dziedziny historii botaniki był tom jubileuszowy Kosmosu wydany w $1928 \mathrm{r}$.

${ }^{14}$ Krzemieniewski 1934b, ss. 1-21.

15 Drugi egzemplarz z czarno-białymi ilustracjami był w zbiorach Biblioteki Jagiellońskiej w Krakowie.

16 Praca Boyma powstała jeszcze przed wprowadzeniem systemu binominalnego w nazewnictwie gatunków przez Karola Linneusza (1707-1778). 
podją mianowicie próbę rozpoznania zamieszczonych tam roślin. Zweryfikował jednocześnie oznaczenia gatunkowe zaproponowane przez wcześniejszych uczonych, przede wszystkim przez Bolesława Namysłowskiego (1882-1929), który wydał jeden z pierwszych artykułów $\mathrm{w}$ języku polskim dotyczący działalności botanicznej Boyma ${ }^{17}$. Krzemieniewski był natomiast pierwszym polskim autorem, który podał propozycje oznaczeń dla wszystkich roślin opisanych we Flora Sinensis. Aktualnie dzieło misjonarza jest uważane za interdyscyplinarne i poddawane analizom przez różnych specjalistów ${ }^{18}$.

Kontynuacją w pewnym stopniu tej wcześniejszej pracy jest drugi artykuł Krzemieniewskiego opublikowany w 1938 r. noszący tytuł „Przyczynek do znajomości spuścizny botanicznej Michała Boyma”19. Uczony miał dostęp do map Chin wykonanych przez jezuitę, których kopie udało się pozyskać Uniwersytetowi Jana Kazimierza we Lwowie ${ }^{20}$, a których oryginały zachowały się w zbiorach Biblioteki Watykańskiej. Badacz ponownie podjął się identyfikacji roślin, tym razem na podstawie potocznych nazw oraz kolorowych przedstawień namalowanych na mapach przez Boyma. Krzemieniewskiemu udało się oznaczyć kilka nowych gatunków, o których jezuita nie wspominał we Flora Sinensis. Uczony doszedł przy tym do interesującego wniosku - stwierdził mianowicie, że są to rośliny ozdobne i dlatego nie znalazły się one we wspomnianym dziele misjonarza ${ }^{21}$. Jego artykuł jest tym cenniejszy, że mapy te prawdopodobnie nie zostały nigdy wydane w całości drukiem ${ }^{22}$.

Do ważnych prac Krzemieniewskiego należy także publikacja przedstawiająca historię botaniki w ośrodku lwowskim bazująca na licznych materiałach historycznych ${ }^{23}$. Została ona wydana w 1934 r. pt. Kartka

17 Wcześniejszą publikacją w języku polskim była praca Zakrzewskiego (Zakrzewski 1830, s. 63-79), w której nie było jednak tak dokładnych oznaczeń roślin, jak w artykule Namysłowskiego.

${ }^{18}$ Na przykład: Köhler 2004, ss. 153-170; Miazek 2005, ss. 289.

19 Krzemieniewski 1938b, ss. 215-225.

${ }^{20}$ Kopie map pozyskano po opublikowaniu pierwszego artykułu przez S. Krzemieniewskiego i jest bardzo prawdopodobne, że stało się to dzięki jego inicjatywie.

${ }^{21}$ Dzieło Boyma zawierało rośliny używane w medycynie chińskiej oraz jadalne.

${ }^{22}$ Krzemieniewski w swojej pracy także zamieszcza tylko wybrane podobizny roślin pochodzące $z$ map Boyma.

${ }^{23}$ Krzemieniewski poddał analizie publikacje opisywanych uczonych - zarówno naukowe, jak i opisy ich podróży badawczych. Korzystał także z kroniki uczelni, ar- 
z dziejów botaniki w Polsce $e^{24}$. Używając barwnego języka uczony scharakteryzował sylwetki botaników pracujących we Lwowie. Nie koncentrował się jedynie na suchych faktach, ale wplótł w tekst rozmaite ciekawostki oraz opinie o uczonych, niezwykle obrazowo przedstawiając charakterystykę ich osobowości i aktywności. Zwrócił przy tym uwagę zarówno na mocne, jak i słabe strony ich działalności. Szczególnie szeroko zostali przez Krzemieniewskiego opisani następujący botanicy: Teofil Ciesielski (1846-1916), Baltazar Hacquet (1740-1815), Hiacynt Lobarzewski (1818-1862), Burchard S. Schivereck (1742-1807), Adolf Weiss (1837-1894), Ernst D. Wittmann (1780-1836), Aleksander Zalewski (1854-1906) i Alexander Zawadzki (1798-1868). W tekście pracy można również odnaleźć zarys dziejów powstawania lwowskiego Ogrodu Botanicznego.

Najliczniejszą część dorobku Krzemieniewskiego z dziedziny historii botaniki stanowią biografie oraz wspomnienia o uczonych. Należą tu prace przedstawiające koleje życia oraz działalność współczesnych mu botaników, takich jak: Bronisław Dębski (1874-1927) ${ }^{25}$, Emil Godlewski sen., Władysław M. Kozłowski (1858-1935)26. W.M. Kozłowski zajmował się dwiema odrębnymi dziedzinami wiedzy: zarówno filozofia, jak i botanika. Mimo że pisał prace botaniczne, był tłumaczem oraz autorem podręczników z botaniki ogólnej przeznaczonych dla studentów, prawdopodobnie byłby zapomniany jako przyrodnik. Dzięki artykułowi Krzemieniewskiego przypomniana została szerzej jego działalność botaniczna. Dopiero w latach sześćdziesiątych XX w. uczony ten doczekał się pełniejszej biografii wraz z zestawieniem jego publikacjii ${ }^{27}$. Życie i działalność kolejnego opisanego przez Krzemieniewskiego botanika - B. Dębskiego, ucznia Edwarda Strasburgera (1844-1912), który zajmował się anatomią i fizjologią roślin, cytologia ramienic, a także entomologią i arachnologia, również nie była przedmiotem wielu opracowań, a jednym z nielicznych jest wspomniany artykul.

tykułów wspomnieniowych i historycznych, spisów wykładów, a nawet odręcznych dedykacji w książkach. Praca zawiera liczne cytaty z tych materiałów.

${ }^{24}$ Krzemieniewski 1934a, ss. 13-31.

${ }^{25}$ Krzemieniewski 1929, ss. 395-397.

${ }_{26}$ Krzemieniewski 1938c, ss. 29-35.

${ }^{27}$ Gawecki 1961, ss. 78. 
Szczególnie jednak dokładnie, w kilku dużych pracach, S. Krzemieniewski nakreślił życie, zasługi naukowe oraz organizacyjne swojego nauczyciela i mistrza Emila Godlewskiego sen. ${ }^{28}$. Jedna z publikacji jemu poświęconą rozpoczyna słowami Adama Mickiewicza pochodzącymi z I księgi Pana Tadeusza: „Zawżdy z wawrzynów drzewo wolności wykwita"29. Podsumowują one w szczególny sposób życie tego znakomitego uczonego, widziane na tle losów Polski. Krzemieniewski w swoich publikacjach niejednokrotnie odwołuje się do Pana Tadeusza, co świadczy o jego wyjątkowym stosunku do tego dzieła ${ }^{30}$. Wspomniane publikacje można zaliczyć do ważnych materiałów źródłowych, gdyż uczony, a także jego żona, należeli do najbliższych uczniów i współpracowników profesora Godlewskiego w jego krakowskiej pracowni naukowej w Studium Rolniczym UJ. Pracowali tu także m.in.: Michał Zając Korczewski (1889-1954) i Władysław Vorbrodt (1883-1940). Sam Krzemieniewski daje też świadectwo humanistycznej atmosfery w niej panującej, takimi słowami wspominając rozmowy inicjowane przez swojego mistrza: „Z najbliższym otoczeniem w pracowni dzielił się wrażeniami z czytanych dzieł literackich, z wydarzeń z życia społecznego"31. Można przypuszczać, że dyskusje na takie tematy zachęcały młodych adeptów nauki do zapoznawania się z interesującymi lekturami, jak również do rozwoju własnych zainteresowań humanistycznych.

Zainteresowanie Krzemieniewskiego biografistyką potwierdzaja ponadto zachowane w Archiwum Polskiej Akademii Nauk biogramy botaników i przyrodników ${ }^{32}$, które były przygotowywane do wydawnictwa Żywoty Polskie $e^{33}$. Objęły one głównie polskich uczonych. Zostały opisane aż dwadzieścia dwie osoby, takie jak: Jerzy Aleksandrowicz (1818-1894), Franciszek Błoński (1867-1910), Teofil Ciesielski (1846-1916), Leon Cienkowski (1822-1887), Ludwik Dębicki, Bogumir

${ }^{28}$ Dwa artykuły wspomnieniowe: Krzemieniewski 1930, ss. 265-275; Krzemieniewski 1931b, ss. 125-137 oraz jeden jubileuszowy: Krzemieniewski 1927, ss. 89-100.

${ }^{29}$ Krzemieniewski 1931b, s. 125.

30 Wśród botaników, którzy niezwykle cenili Pana Tadeusza był m.in. Marian Raciborski, a książka ta towarzyszyła mu podczas pracy na Jawie, była także jego ostatnia lekturą w sanatorium Kazimierza Dłuskiego w Zakopanem, gdzie zmarł w 1917 r. zob. Piekiełko-Zemanek 1986, s. 38.

31 Krzemieniewski 1930, s. 274.

32 Archiwum PAN Warszawa: sygn. III - 174.

33 Nazwa ta pojawia się w materiałach archiwalnych. 
Eichler (1843-1905), Roman Gutwiński (1860-1932), Stanisław Bonifacy Jundziłł (1761-1847), Franciszek Kamieński (1851-1912), Krzysztof Kluk (1739-1796), Roman Kobendza (1886-1955), Józef Krupa (1850-1889), Feliks Kwieciński (1850-1932), Bolesław Namysłowski (1882-1929), Marian Raciborski (1863-1917), Władysław Rothert (1863-1916), Józef Rostafiński (1850-1928), Franciszek Ksawery Skupieński (1888-1962), Maria Twardowska (1858-1907), Jakób Waga (1800-1872), Aleksander Zawadzki (1798-1868). Wśród nich znalazł się także francuski lekarz i przyrodnik Jean Emmanuel Gilibert (17411884), pracujący na dawnych ziemiach polskich. Większość z przygotowanych biogramów prawdopodobnie nigdy nie ukazała się drukiem. Niektóre z nich z pewnością napisała Helena Krzemieniewska - żona Krzemieniewskiego, która przypuszczalnie kontynuowała projekt po śmierci swojego męża. Dowodzą tego nazwiska botaników, którzy przeżyli Krzemieniewskiego ${ }^{34}$. Materiały te były być może przygotowywane jako odpowiedź na apel inicjatorów Polskiego Stownika Biograficznego. W wydawnictwie tym, życiorysy osób wymienionych wyżej są jednak autorstwa różnych uczonych ${ }^{35}$. Jedynie biogram T. Ciesielskiego został opracowany przez S. Krzemieniewskiego ${ }^{36}$, który ponadto jest autorem życiorysu innego botanika związanego ze Lwowem - Karola Borowiczki (1842-1904) $)^{37}$.

Do prac bibliograficznych, typowo interdyscyplinarnych, które wymagały znajomości zarówno botaniki, jak i nauk rolniczych można zaliczyć pozycję S. Krzemieniewskiego pt. Próba bibliografji doświadczalnictwa $(1928)^{38}$.

\section{Działacz na polu ochrony przyrody}

Niezwykle interesujące w działalności S. Krzemieniewskiego jest to, że prowadząc żmudne badania laboratoryjne, równocześnie potrafił

${ }^{34}$ Jest to R. Kobendza i F.K. Skupieński; być może H. Krzemieniewska przygotowała również życiorys M. Twardowskiej, a wywnioskować to można na podstawie podobnych zainteresowań naukowych obu badaczek (dotyczących śluzowców).

35 Biogramy te opracowali: S. Brzozowski, A. Dzięczkowski, B. Hryniewiecki, Z. Kosiek, W. Sławiński.

${ }^{36}$ Krzemieniewski 1938a, ss. 60-61.

37 Krzemieniewski 1936, s. 344.

38 Krzemieniewski 1928, ss. 16. 
włączyć się w prace mające zupełnie inny charakter, a więc upowszechnianie problemów z zakresu ochrony przyrody. Jego publikacje kierowane były do szerokich kręgów społeczeństwa. Jest bardzo prawdopodobne, że znaczący wpływ na rozwinięcie się wrażliwości na wspomniane tematy mial jego dwuletni pobyt (lata 1900-1902) w Dublanach pod Lwowem, jako asystenta w pracowni botanicznej Mariana Raciborskiego (1863-1917) ${ }^{39}$ - współtwórcy ochrony przyrody w Polsce. Właśnie w tamtym czasie, w 1900 r., Raciborski powrócił na ziemie polskie po czteroletnim pobycie na wyspie Jawie - w holenderskiej kolonii, gdzie prowadził badania naukowe oraz gromadził zbiory przyrodni$\mathrm{cze}^{40}$. Po powrocie rozpoczyna on intensywną działalność w zakresie ochrony przyrody, która trwa aż do śmierci uczonego w 1917 roku ${ }^{41}$. Tak pisze o tym wielkim zaangażowaniu jego wybitny uczeń Władysław Szafer $(1886-1970)^{42}$ :

39 Marian Raciborski - botanik; w latach 1886-1892 asystent J. Rostafińskiego w UJ, później K. Goebla w Uniwersytecie w Monachium, gdzie się doktoryzował. W latach 1894-1900 pracował na Jawie. Profesor Akademii Rolniczej w Dublanach, Uniwersytetu Lwowskiego i Jagiellońskiego, gdzie od 1912 r. był dyrektorem Instytutu Botaniki oraz Ogrodu Botanicznego. Wykonywał badania głównie z paleobotaniki, morfologii, florystyki roślin oraz fitopatologii. Propagator ochrony przyrody na ziemiach polskich, świetny organizator pracy zespołowej - zob. Kornaś 1986, ss. 160 .

40 Zemanek 2000c, ss. 115-127.

41 W. Szafer (1965, s. 65) twierdzi, że Raciborski już w 1900 r. rozpoczął działania związane z ochrona przyrody, ale nie podaje konkretnych przykładów jego prac z tego początkowego okresu. Na pewno działania mające za cel inwentaryzację najcenniejszych zabytków przyrody w zaborze austriackim ruszyły od 1904 r., a pierwsza publikacja Raciborskiego na ten temat ukazała się w 1908 r. Uważa się, że jednym z inspiratorów jego działalności ochroniarskiej był Hugon Conwentz (1855-1922), paleobotanik i pionier ruchu ochroniarskiego na ziemiach niemieckich. Raciborski korespondował z nim prowadząc własne prace paleobotaniczne i mógł zaraz po powrocie z Jawy zainteresować się jego działaniami ochroniarskimi oraz znać jego pracę wydaną w 1900 r. w Berlinie pt. Forstbotanishes Merkbuch für Westpreussen - zob. Szafer 1965, ss. 71-72; Zemanek 2019, 130-131.

42 Władysław Szafer - botanik; studiował w Wiedniu, specjalizując się pod kierunkiem R. Wettsteina. Następnie był asystentem M. Raciborskiego, a także jego następcą na UJ w Krakowie jako prof. botaniki i dyrektor Ogrodu Botanicznego. Położył duże zasługi na polu ochrony przyrody. Prowadził wszechstronną działalność organizacyjną i naukowa, pozostawił po sobie ogromny dorobek naukowy - jest autorem ok. 700 pozycji bibliograficznych - zob. Szafer 2000d, ss. 185-197. 
Wygłaszał na ten temat liczne odczyty publiczne we wszystkich niemal miastach Polski, a nawet w miasteczkach prowincjonalnych (...). Odczyty te, a także wykłady o ochronie przyrody, wygłaszane ze szczerym uczuciem i przejęciem $z$ katedr uniwersyteckich $w$ Krakowie w latach 1910-1914, jednały licznych zwolenników nowej idei, której Raciborski był prawdziwym apostołem. Posiadał także wielki talent organizatorski i umiał użytkować go w służbie ochrony przyrody, przyciagając do niej szeregi współpracowników ${ }^{43}$.

Krzemieniewski był z pewnością pod wpływem niezwykłej osobowości Raciborskiego i w późniejszych latach włączył się w organizowany przez niego ruch ochroniarski. W tym jednak czasie młody badacz był dopiero u progu swojej kariery naukowej, a jego ówczesne zainteresowania kierowały się w stronę badań eksperymentalnych ${ }^{44}$. Po dwóch latach pracy z Raciborskim, Krzemieniewski wrócił do Krakowa do pracowni E. Godlewskiego sen. na UJ, otrzymując tam stanowisko asystenta. Na tej uczelni doktoryzował się w 1905 r., a habilitował w 1909 r. Od 1909 aż do 1941 r. był powtórnie związany z ośrodkiem lwowskim, najpierw jako prof. botaniki w Akademii Rolniczej w Dublanach pod Lwowem, a następnie (1919-1941) jako profesor anatomii i fizjologii roślin na Uniwersytecie Jana Kazimierza. W początkowych latach lwowskich mógł on ponownie zetknąć się z działalnością M. Raciborskiego, który pracował tutaj do 1912 r., i jak wspominał W. Szafer „był duszą wszelkich poczynańn ${ }^{45}$ " na polu ochrony przyrody.

Szeroko zakrojone działania Raciborskiego znalazły kontynuację już po odzyskaniu przez Polskę niepodległości, kiedy postanowiono powołać instytucję państwowa, która miała za cel wprowadzać w życie idee ochrony przyrody. W 1920 r., dzięki inicjatywie W. Szafera, powstała Państwowa Rada Ochrony Przyrody, której Wydział Główny znajdował się w Krakowie, a w pozostałych miastach uniwersyteckich (Lwów, Poznań, Warszawa i Wilno) zostały powołane do życia

43 Szafer 1965, ss. 53-123.

44 Świadczy o tym treść listu S. Krzemieniewskiego do E. Godlewskiego sen.; Lwów, 29 grudnia 1901 r. (Arch. UJ: sygn. D IV-8).

45 Szafer 1965, s. 65. 
Komitety Ochrony Przyrody (od 1937 r. Oddziały PROP). W Komitecie powstałym we Lwowie do czołowej grupy działaczy W. Szafer zaliczył także S. Krzemieniewskiego ${ }^{46}$, obok takich wyróżniających się w zakresie ochrony przyrody osób jak: Aleksander Kozikowski (1879_ 1956) ${ }^{47}$, Stanisław Kulczyński (1895-1975) ${ }^{48}$, Jan Gwalbert Pawlikowski (1860-1939) ${ }^{49}$ oraz Szymon Wierdak (1883-1949) ${ }^{50}$. Właśnie w tym okresie, czyli w latach dwudziestych XX w., powstają wszystkie publikacje Krzemieniewskiego poświęcone ochronie przyrody. Co więcej włączają się one tematycznie w podstawowy nurt działalności PROP w okresie międzywojennym. Rada prowadziła przede wszystkim działania na polu konserwatorskiej ochrony przyrody, ponadto była zaangażowana w edukację społeczeństwa, zwłaszcza młodzieży (dzięki staraniom Rady wprowadzono do programu szkół ogólnokształcących treści ochroniarskie $)^{51}$, ponadto zajmowała się ona także opiniowaniem projektów ustaw gospodarczych ${ }^{52}$.

46 Szafer 1965, s. 85.

47 Aleksander Kozikowski - leśnik, entomolog; profesor w Wyższej Szkole Lasowej we Lwowie, oraz Politechnice Lwowskiej, a po II wojnie światowej profesor ochrony lasu Uniwersytetu Poznańskiego. Autor ponad stu prac z zakresu entomologii leśnej i ogólnej, botaniki leśnej, ochrony roślin i lasu, ochrony przyrody i in. związanych z zagadnieniami leśnymi - zob. Brzozowski 1987, s. 288.

${ }^{48}$ Stanisław Kulczyński - botanik, polityk; uczeń M. Raciborskiego i W. Szafera; adiunkt Ogrodu Botanicznego w Krakowie; sekretarz Państwowego Komitetu Ochrony Przyrody (1921-1924) - brał udział w opracowaniu projektu Parku Narodowego w Pieninach, profesor Uniwersytetu we Lwowie, po II wojnie światowej rektor Uniwersytetu i Politechniki we Wrocławiu; opracowywał hasła do Flory Polskiej, był współautorem Roślin polskich, czyli tzw. Małej Flory Polskiej (1924) - zob. Mularczyk, Kuźniewski 2018, ss. 367.

${ }^{49}$ Jan Gwalbert Pawlikowski - prawnik, pisarz, zaangażowany działacz ochrony przyrody; profesor ekonomii, statystyki i administracji w Akademii Rolniczej w Dublanach. Ponadto czołowy taternik i badacz jaskiń tatrzańskich, współzałożyciel Sekcji Ochrony Tatr przy Towarzystwie Tatrzańskim (1912), inicjator pierwszego projektu Tatrzańskiego Parku Narodowego (1913), główny współautor pierwszej polskiej ustawy o ochronie przyrody (1934) - zob. Radwańska-Paryska1987, ss. 214-215.

${ }^{50}$ Szymon Wierdak - botanik, dendrolog; uczeń M. Raciborskiego, profesor botaniki leśnej Politechniki Lwowskiej. Po II wojnie światowej objął katedrę botaniki leśnej na Uniwersytecie Jagiellońskim. Kierował wiele lat Oddziałem PROP we Lwowie zob. Karpowiczowa 1987, s. 571.

51 Co miało miejsce w latach 30. XX w.

52 Szafer 1965, ss. 90-95. 
Pierwszy, duży artykuł S. Krzemieniewskiego należący do tej tematyki pt. „Ochrona Przyrody Ojczystej i jej znaczenie” powstał na podstawie wygłoszonego przez niego referatu na posiedzeniu Lwowskiej Kuratorji Ochrony Przyrody i został wydany w dwóch częściach w czasopiśmie Prayroda i Technika $\mathrm{w} 1922 \mathrm{r}^{53}$ Następnie był opublikowany jako osobna broszura w serii Biblioteka „Prayrody $i$ Techniki” w kolejnym roku (1923) przez Książnicę Polską Towarzystwa Nauczycieli Szkół Wyższych w Wydawnictwie Polskiego Towarzystwa Przyrodników im. Kopernika ${ }^{54}$. Mówiąc w tej pracy o ochronie przyrody Seweryn Krzemieniewski odwołał się do dwóch ważnych dzieł polskiej literatury. Cytuje epopeję narodowa Pan Tadeusz Adama Mickiewicza oraz nowelę góralską $O$ Wojtku cudaku ze zbioru Na skalnym Podhalu Kazimierza Przerwy-Tetmajera. Oba dzieła literackie zawierają niezwykle barwne i nierzadko szczegółowe opisy przyrody i roślin, stąd też wydają się bliskie ludziom zajmującym się zawodowo botaniką. W swoim artykule poprzez słowa tych właśnie piewców piękna przyrody polskiej Krzemieniewski chciał ukazać jej wyjątkowość i podkreślić jej swojskość uwidocznioną dzięki silnemu związkowi z przyrodą ludzi żyjących na konkretnej ziemi - na Litwie, Podhalu czy w jeszcze innych regionach zamieszkanych przez Polaków. Krzemieniewski motywował konieczność ochrony natury poprzez ukazanie głębokiego jej znaczenia dla zwykłego człowieka, który nierzadko był z nią mocno zżyty i która również określała jego tożsamość.

Odwołując się do tych utworów literackich i używając sugestywnych określeń zapożyczonych od wspomnianych poetów, Krzemieniewski wypowiada bardzo charakterystyczne słowa: „,...powinniśmy mieć zrozumienie dla tych, co z ziemią nasza gadają $a^{55}$, tajniki jej zgłębiaja, lub z piękna jej czerpią natchnienie. ...byłoby grzechem nie mieć zrozumienia dla tych cudaków ${ }^{56}$ i pracy im nie ułatwic ${ }^{57}$. Jest to wyrażenie po-

${ }^{53}$ Krzemieniewski 1922, ss. 85-97.

${ }^{54}$ Krzemieniewski 1923b, ss. 20.

55 „Z ziemią naszą gadaja” - Krzemieniewski cytuje tu Pana Tadeusza, Księgę II: „Zamek”.

${ }^{56}$ „Cudaków” - Krzemieniewski cytuje tu nowelę O Wojtku cudaku ze zbioru $\mathrm{Na}$ skalnym Podhalu - jej bohaterem jest Wojtek, który wolał obcować z przyrodą niż z ludźmi, przez co był nazywany cudakiem.

${ }^{57}$ Krzemieniewski 1923, ss. 20. 
chwały i poparcia dla każdej działalności, która ma na celu poznanie i ochronę przyrody ziem polskich.

W dalszej części artykułu uczony przywołał wszystko to, co we florze polskiej jest najcenniejsze, referując czytelnikowi rezultaty dotychczasowej intensywnej inwentaryzacji przyrody ziem polskich, która była organizowana między innymi przez Raciborskiego. Krzemieniewski zwrócił uwagę zarówno na okolice znanego sobie Lwowa, ale również na Pieniny, odnotował także wyjątkowość Puszczy Białowieskiej oraz dużego stanowiska cisa w Kniaźdworze koło Kołomyi, wspomniał także relikty we florze polskiej, np. wierzbę lapońską koło Bełza czy azalię pontyjską koło Leżajska. Nie zapomniał także o specyficznych roślinach wybrzeża czy torfowisk. W pracy przypomniał o pomnikach przyrody - największych drzewach, a jednocześnie świadkach przeszłych czasów na ziemi polskiej. Przy końcu pracy uczony mocno nawoływał do pogłębiania wiedzy przyrodniczej i poszerzania świadomości związanej z ochroną przyrody na każdym szczeblu edukacji w Polsce, zarówno jeśli chodzi o nauczanie w szkołach podstawowych, jak i średnich czy wyższych ${ }^{58}$. Przestrzegał także przed złymi, a tak powszechnymi nawykami, jak np. ryciem napisów na drzewach i skałach, zbieraniem dzikich roślin w celu sprzedaży na targach czy wyniszczającym pozyskiwaniem w wielkich ilościach roślin leczniczych. Jego pragnieniem było, aby powstało towarzystwo, którego celem będzie ochrona ojczystej przyrody, a które powinno objąć jak najszersze kręgi społeczeństwa.

Natomiast już w lutym 1923 r. S. Krzemieniewski na łamach Kuriera Lwowskiego opublikował artykuł o charakterze interwencyjnym, wzywający społeczeństwo do przeciwstawienia się rabunkowej eksploatacji kosodrzewiny w obrębie ustanowionego wcześniej rezerwatu w paśmie Czarnohory, przedstawiając tekst pod wymownym tytułem: „Czy to być może?”. Treść tego artykułu, jako bardzo istotna, została przedrukowana w specjalistycznym miesięczniku Sylwan, zaraz w następnym miesiącu tego samego roku ${ }^{59}$. Kilka lat później, w 1926 r., w czasopiśmie Ochrona Prayrody uczony będzie zaś nawoływał do ochrony wzgórza Chomiec na zachodnim krańcu Krzywczyc pod Lwowem z cenną

58 Jego postulaty zostały później częściowo zrealizowane poprzez wprowadzenie zagadnień z ochrony przyrody do szkół ogólnokształcących - o czym było wspomniane wyżej.

${ }^{59}$ Krzemieniewski 1923a, ss. 49-52. 
florą i fauna, głównie stepowa, i proponował utworzenie tam rezerwa$\mathrm{tu}^{60}$. Jednym $\mathrm{z}$ ważnych argumentów, którym dodatkowo motywował konieczność wzięcia pod ochronę tego miejsca, była bliskość miasta Lwowa, a więc możliwość wykorzystania rezerwatu w celu edukacji lwowskiej młodzieży i studentów. W takim podejściu po raz kolejny odbija się jego pasja rozpowszechniania wiedzy przyrodniczej wśród młodych ludzi.

Mimo dużego, osobistego zaangażowania Krzemieniewskiego w sprawy ochrony przyrody polskiej wyraźnie widocznego w jego publikacjach, to po roku 1926 nie podejmuje on więcej tej tematyki. Członkiem PROP był stosunkowo krótko, jedynie w latach 1923-192561. Nie wiadomo co spowodowało porzucenie tej aktywności, być może działalność ta wymagała od uczonego poświęcenia zbyt dużo czasu, który był mu potrzebny do prowadzenia eksperymentów naukowych nad miksobakteriami. Właśnie w 1926 r. ukazuje się pierwsza część pracy S. i H. Krzemieniewskich dotycząca tych bakterii, a temu tematowi poświęca następnie wiele lat intensywnych badañ ${ }^{62}$. Ochrona przyrody straciła może jednego ze swoich gorących orędowników, ale zyskała nauka polska i światowa, ponieważ badania te przyniosły doniosłe odkrycia z zakresu mikrobiologii.

\section{Popularyzator wiedzy przyrodniczej}

Wiedza przyrodnicza była rozpowszechniana przez S. Krzemieniewskiego przede wszystkim poprzez publikowanie artykułów popularnonaukowych. Ich tematyka obejmowała przede wszystkim fizjologię roślin oraz zagadnienia botaniczne nawiązujące do kwestii ogrodniczych. Ukazywały się w czasopismach: $W$ szechświat, Kosmos oraz Ogrodnictwo. Krzemieniewski rozpoczął tę działalność jako bardzo młody człowiek, będąc jeszcze studentem na Uniwersytecie Jagiellońskim. W 1897 r. we $W$ szechswiecie opisał wydzielanie związków chemicznych przez korzenie roślinne ${ }^{63}$. Zwracał uwage na praktyczny aspekt tego zjawiska - substancje te pozwalały na rozkład pewnych składników podłoża i dzięki temu

\footnotetext{
${ }^{60}$ Krzemieniewski 1926, ss. 72-75.

${ }^{61}$ Szafer 1965, s. 121.

62 Badura 1969, s. 13.

${ }_{63}$ Krzemieniewski 1897, ss. 369-371.
} 
umożliwiały ich pobranie przez rośliny. Kolejny artykuł (1899) dotyczył roślinnych komórek i gruczołów wydzielających wodę oraz mechanizmów tego wydzielania ${ }^{64}$. Natomiast w Ogrodnictwie wydał pracę pod tytułem: „O poglądach na tworzenie się kwiatów” (1906) ${ }^{65}$. Jednocześnie Krzemieniewski rozpowszechniał wiedzę rolniczą. W Kosmosie ukazała się jego publikacja skierowana do rolników pt. „Fosforyty jako nawóz" ${ }^{\prime 6}$. Wydawał także prace, które dotyczyły wyników jego własnych badań związanych z efektywna uprawą łąk oraz pastwisk w terenach podgórskich i górskich, między innymi w Tygodniku Rolniczym (1902, 1907) oraz w Roczniku Nauk Rolnicsych (1907 ${ }^{67}$. Uczony przedstawiał również rezultaty prac z zakresu mikrobiologii, a dotyczące bakterii glebowych z rodzaju Azotobacter ${ }^{68}$. Natomiast tylko w rękopisie pozostał szkic artykułu popularnonaukowego o ciekawym tytule: „Życie w mrokach ziemi" ${ }^{69}$.

Krzemieniewski dał się poznać ponadto jako autor recenzji prac innych uczonych, które wydawał w Ogrodnictwie, Kosmosie, Rocznikach Nauk Rolniczych i Leśnych. Na przykład w czasopiśmie Ogrodnictwo omówił znacząca publikację naukową autorstwa Edwarda Janczewskiego pt. Monografia porzecžki prof. Janczৃenskiego ${ }^{70}$, ówcześnie ważną pozycję dla botaników, rolników i ogrodników, która do dnia dzisiejszego nie została zastapiona przez nowsze, całościowe opracowanie ${ }^{71}$.

Popularyzacja wiedzy przyrodniczej u S. Krzemieniewskiego objawiała się nie tylko w publikacjach, ale również w jego bezpośredniej działalności edukacyjnej skierowanej do rozmaitych grup ludzi. W biografiach Krzemieniewski jest wspominany jako bardzo dobry pedagog i znakomity mówca. Jeszcze w czasach asystentury u prof. E. Godlewskiego sen. w Studium Rolniczym UJ został wykładowcą na wakacyjnym kursie uniwersyteckim dla nauczycieli ludowych, który odbył się w Cieszynie w sierpniu 1904 r. Tytuł jego wykładów obejmował zagadnienia

${ }^{64}$ Krzemieniewski 1899, ss. 216-218.

${ }^{65}$ Krzemieniewski 1906, ss. 4-9.

${ }^{66}$ Krzemieniewski 1931a, ss. 142-166.

${ }^{67}$ Krzemieniewski 1902, ss. 194-195; Krzemieniewski 1907a, ss. 145-222; Krzemieniewski 1907b, ss. 386-387.

${ }^{68}$ Krzemieniewski 1909, ss. 127-242.

${ }^{69}$ Archiwum PAN Warszawa: sygn. III - 174.

${ }^{70}$ Krzemieniewski 1908, ss. 60-61.

${ }^{71}$ Kulpiński 2011, ss. 117-123. 
fizjologii roślin i brzmiał: „Budowa i żywienie się roślin” (6 godzin) ${ }^{72}$. Natomiast już w kolejnym roku (1905) prowadził zajęcia w ramach Zakopiańskiego Uniwersytetu Wakacyjnego. Pod jego opieką naukową odbyła się wycieczka w Tatry, uczony wygłosił również wykład ${ }^{73}$, który prawdopodobnie dotyczył łąk i pastwisk górskich, ponieważ aktualnie nad tym tematem pracował. W tym okresie był także wykładowcą na kursach agrotechnicznych w Uniwersytecie Ludowym i Uniwersytecie Powszechnym w Krakowie ${ }^{74}$.

Troska Krzemieniewskiego o właściwą edukację nauczycieli, a przez to właściwe przekazywanie wiedzy młodzieży, i co za tym idzie kształtowanie postaw przyrodniczych w społeczeństwie, uwidoczniła się także i w tym, że pomimo innych licznych obowiązków był członkiem lwowskiej Komisji Egzaminacyjnej dla kandydatów na nauczycieli, mianowany do egzaminu z nauk biologicznych. Funkcję tę pełnił przez okres przynajmniej trzech lat: 1924-1926 $6^{75}$.

\section{Podsumowanie}

W artykule przedstawiono wybraną część działalności Seweryna Józefa Krzemieniewskiego, obejmującą zainteresowania humanistyczne i interdyscyplinarne, a nie poddaną wcześniej dokładniejszemu rozważaniu i analizie. Pozwala to spojrzeć na człowieka nauk eksperymentalnych oraz badacza tajemnic mikrobiologii z zupełnie innej perspektywy. Dzięki temu jest możliwe nakreślenie bardziej całościowego wizerunku tego badacza. Uczony tej miary co Krzemieniewski z pewnością zasługuje na rzetelną i nowoczesną biografię, a przedstawione powyżej studium może stanowić istotne jej uzupełnienie.

$\mathrm{Na}$ zwrócenie się twórczości Krzemieniewskiego w kierunku humanistycznym miała niewątpliwie wpływ inspirująca atmosfera panująca w Krakowie na przełomie wieków XIX i XX, z którą zetknął się po przyjeździe do tego miasta, oraz kontakt z wybitnymi uczonymi tamtych czasów o szerokich poglądach i zainteresowaniach, a szczególnie z botanikami: Emilem Godlewskim sen., Marianem Raciborskim

${ }^{72}$ Informację o wykładach podaje m.in.: Miesięcznik Pedagogiczny, R. 13, Nr 4. 1904.

${ }^{73}$ Kowalik 2006, ss. 114-118.

${ }^{74}$ Rakoczy 2000, ss. 155-164.

75 Zagórowski 1924, ss. 118. 
czy Józefem Rostafińskim. W późniejszym czasie na jego działalność wpłynął również entuzjazm narodu polskiego, w tym środowisk akademickich, wynikający z odzyskania przez Polskę niepodległości, co przyczyniło się do powstania PROP i prowadzenia w jej obrębie szeroko zakrojonych działań na rzecz ochrony polskiej przyrody, w które z takim zaangażowaniem się włączył. Nie bez znaczenia na humanistyczną aktywność uczonego miały też jego cechy osobowości, takie jak zdolności oratorskie, zamiłowanie do przekazywania wiedzy, wrażliwość na przyrodę, a także wielka troska o właściwą edukację przyrodniczą społeczeństwa polskiego.

\section{Bibliografia}

\section{ZBIORY ARCHIWALNE}

Archiwum Uniwersytetu Jagiellońskiego. Spuścizna Emila Godlenskiego sen. Korespondencja. sygn. D IV-8: list Seweryna Krzemieniewskiego do Emila Godlewskiego sen.; Lwów, 29 grudnia $1901 \mathrm{r}$.

Archiwum PAN w Warszawie. Materiaty Seweryna i Heleny Krzemieniewskich. sygn. III- 174.

\section{OPRACOWANIA}

Badura, Lesław 1969: Naukowe dzieło Heleny i Seweryna Krzemieniewskich. Wiadomości Botaniczne XII(1), ss. 9-21.

Brzozowski, Stanisław 1987: Kozikowski Aleksander (1879-1956). [W:] Stownik biologón polskich, pod redakcją Stanisława Feliksiaka. Warszawa: Państwowe Wydawnictwo Naukowe. ISBN 83-01-00656-0.

Gawecki, Bolesław 1961: Władysław Miecaystaw Kozłowski. Wrocław: Zakład Narodowy im. Ossolińskich, ss. 78.

Hryniewiecki, Bolesław 1948: Seweryn Krzemieniewski (1871-1945). Wspomnienie pośmiertne. Acta Societatis Botanicorum Poloniae XIX. ss. 284-292.

Karpowiczowa, Ludmiła 1987: Wierdak Szymon (1883-1949). [W:] Stownik biologów polskich, pod redakcją Stanisława Feliksiaka. Warszawa: Państwowe Wydawnictwo Naukowe. ISBN 83-01-00656-0.

Köhler, Piotr 2004: Jezuici w diiejach botaniki polskiej. [W:] Stasiewicz-Jasiukowa, Irena (red.). Wktad jezuitón do nauki i kultury w Rzecapospolitej Obojga Narodów i pod zaborami. Kraków - Warszawa: Komitet Historii Nauki i Techniki PAN, Wyższa 
Szkoła Filozoficzno-Pedagogiczna „Ignatianum”, Wydawnictwo „WAM”. ISBN 8373184821.

Kornaś, Jan (red.) 1986: Marian Raciborski. Studia nad syciem i działalnościq naukowa. De Mariani Raciborski vita et scriptis. Warszawa - Kraków, Uniwersytet Jagielloński, Varia t. CCX, PWN, Nakł. UJ. ISBN 83-01-07342-X.

Kowalik, Tomasz 2006: Rodowód Akademickiego Klubu Turystycznego. Gościniec Polskiego Towarzystwa Turystyczno-Krajoznawczego, 2 (23), ss. 114-118.

Krzemieniewski, Seweryn 1897: Wydzieliny korzeni roślinnych. Wszechświat XVI (24), ss. 369-371.

Krzemieniewski, Seweryn 1899: Narządy roślin wydzielające wodę. Wşechświat XVIII (14), ss. 216-218.

Krzemieniewski, Seweryn 1902: Gospodarstwo łąkowe w górach. Tygodnik Rolniçy 19 (22), ss. 194-195;

Krzemieniewski, Seweryn 1906: O poglądach na tworzenie się kwiatów. Ogrodnictwo 1, ss. 4-9.

Krzemieniewski, Seweryn 1907a: Próby podniesienia uprawy łąk i pastwisk w Tatrach. Rocznik Nauk Rolniczych 3, ss. 145-222.

Krzemieniewski, Seweryn 1907b: Słów kilka o uprawie łąk. Tygodnik Rolniçy 24 (39), ss. 386-387.

Krzemieniewski, Seweryn 1908: Monografia porzeczki prof. E. Janczewskiego. Ogrodnictwo 2, ss. 60-61.

Krzemieniewski, Seweryn 1909: Studia nad Azotobakterem. Rocznik Nauk Rolnicsych 4, ss. 127-242.

Krzemieniewski, Seweryn 1922: Ochrona przyrody ojczystej i jej znaczenie. Prayroda i Technika I(1), ss. 23-27 (cz. 1.); I(2), ss. 85-97 (cz. 2).

Krzemieniewski, Seweryn 1923a: Czy to być może? Sylwan, marzec, ss. 49-52.

Krzemieniewski, Seweryn 1923b: Ochrona przyrody ojczystej i jej znaczenie, Warszawa -Lwów: Książnica Polskiego Towarzystwa Nauczycieli Szkół Wyższych, ss. 20.

Krzemieniewski, Seweryn 1926: Chomiec w Krzywczycach pod Lwowem. Ochrona Pryyrody 6, ss. 72-75.

Krzemieniewski, Seweryn 1927: Emil Godlewski sen. w 80. rocznicę urodzin. Kosmos 52, ss. 89-100.

Krzemieniewski, Seweryn 1928: Próba bibljografji doświadczalnictwa. Warszawa: Drukarnia Rolnicza, ss. 16.

Krzemieniewski, Seweryn 1929: Bronisław Dębski, Acta Societatis Botanicorum Poloniae 6, ss. 395-397. 
Krzemieniewski, Seweryn 1930: Prof. Dr. Emil Godlewski, sen. Zarys działalności naukowej. W szechświat, $\mathrm{Nr}$ 9, ss. 265-275.

Krzemieniewski, Seweryn 1931a: Fosforyty jako nawóz. Kosmos, R. 56, ss. 142-166.

Krzemieniewski, Seweryn 1931b: Prof. Dr. Emil Godlewski (sen.), jako organizator i pedagog. Kosmos, R. 56, z. 2-4, ss. 125-137.

Krzemieniewski, Seweryn 1934a: Kartka z dziejów botaniki w Polsce. Acta Societatis Botanicorum Poloniae, Vol. XI. Suplementum, ss. 13-31.

Krzemieniewski, Seweryn 1934b: Michał Boym jako botanik. Kosmos, ser. B, R. LIX, z. I, ss. 1-21.

Krzemieniewski, Seweryn 1936: Borowiczka Karol. PSB 2, s. 344.

Krzemieniewski, Seweryn 1938a: Ciesielski Teofil. PSB 4, ss. 60-61.

Krzemieniewski, Seweryn 1938b: Przyczynek do znajomości spuścizny botanicznej Michała Boyma. Kosmos, ser. B, R. LXIII, ss. 215-225.

Krzemieniewski, Seweryn 1938c: Władysław M. Kozłowski (wspomnienie). Kosmos, ser. B, R. LXIII, ss. 29-35.

Krzeptowska-Moszkowicz, Izabela 2013: Emil Godlewski senior pionier fiæjologii roślin. Kraków: PAU, Komisja Historii Nauki, Monografie 19. ISBN 978-837676-144-2.

Kulpiński, Kamil 2011: Edwarda Janczenskiego studia nad porzeczkami. Karta z dziejów systematyki XIX-XX w., Warszawa: Komitet Historii Nauki i Techniki PAN. „Rozprawy z Dziejów Nauki i Techniki”, T. 21. ISBN 978-83-61236-34-4.

Majewski, Tomasz 2000: Edward Franciszek Glinka Janczewski (1846-1918). Botanike, systematyk, anatom, morfolog, algolog. [W:] Zemanek, Alicja (red.): Z łota Ksiega Wydziału Biologii i Nauk o Ziemi. Uniwersytet Jagielloński. Cześć I: Biografie uczonych. Kraków, Nakł. UJ, Wydawnictwo Naukowe DWN. ISBN 83-7188-321-8.

Miazek, Monika 2005: Flora Sinensis Michała Boyma SI. Gniezno: Wydawnictwo Fundacji Collegium Europaeum Gnesnense. ISBN 83-922470-2-7.

Mularczyk Magdalena, Kuźniewski Eugeniusz 2018: Nauka jest treścia mojego àycia... Prof. Stanisław Kulcyyński - zycie i drieło. Wrocław: Oficyna Wydawnicza ATUT Wrocławskie Wydawnictwo Oświatowe. ISBN 978-83-7977-355-8.

Piekiełko-Zemanek, Alicja 1986: Kalendarium życia Mariana Raciborskiego. [W:] Kornaś J. (red.), Marian Raciborski. Studia nad zyciem i działalnościa naukowa. Warszawa - Kraków: Państwowe Wydawnictwo Naukowe. ISBN 83-01-07342-X.

Radwańska-Paryska, Zofia 1987: Jan Gwalbert Pawlikowski (1860-1939). [W:] Stownik biologów polskich, pod redakcją Stanisława Feliksiaka. Warszawa: Państwowe Wydawnictwo Naukowe. ISBN 83-01-00656-0. 
Rakoczy, Leokadia 2000: Seweryn Józef Krzemieniewski (1871-1945) - botanik, fizjolog roślin, mikrobiolog gleby. [W:] Zemanek A. (red.): Złota Księga Wydziału Biologii i Nauk o Ziemi. Uniwersytet Jagielloński. Czesśc I: Biografie uczonych. Kraków: Wydawnictwo Naukowe DWN. ISBN 83-7188-321-8.

Szafer, Władysław 1965: Zarys historii ochrony prayrody w Polsce. [W:] Szafer W. (red.). Ocbrona prayrody i jej zasobów. Problemy i metody. Kraków: Polska Akademia Nauk, Zakład ochrony przyrody, T. I, ss. 53-123.

Zagórowski, Zygmunt 1924: Spis nauczycieli: sqkót wyższych, średnich, zawodowych, seminarjów nauczycielskich oraz wykaz zakładów naukowych i władz szkolnych. Lwów Warszawa: Książnica Polska.

Zakrzewski [brak imienia], 1830: Wspomnienie życia i pism Michała Boyma, uczonego wieku siedemnastego. Czasopism Naukowy Ksiegozbioru Publicznego im. Ossolinskich. III(2).

Zemanek, Alicja 1992: Historia botaniki w Polsce - stan i perspektywy rozwoju. Kwartalnik Historii Nanki i Techniki 37 (4), ss. 31-45.

Zemanek, Alicja (red.) 2000a. Jóref Rostafiński. Botanik i bumanista. Kraków: PAU, Komisja Historii Nauki, Monografie 1. ISBN 83-86956-75-5.

Zemanek, Alicja 2000b: Koleje sycia Józefa Rostafinskiego. [W:] Zemanek, Alicja (red.). Józef Rostafinski. Botanik i humanista. Kraków: PAU, Komisja Historii Nauki, Monografie 1. ISBN 83-86956-75-5.

Zemanek, Alicja 2000c: Marian Raciborski, botanik, systematyk, fitogeograf, paleobotanik. [W:] Zemanek A. (red.): Złota Ksiega Wydriału Biologii i Nauk o Ziemi. Uniwersytet Jagiellonski. Cześś I: Biografie uczonych. Złota Ksiega Uniwersytetu Jagiellonskiego. Wydriał Biologii i Nauk o Ziemi. Kraków: Wydawnictwo Naukowe DWN. ISBN 83-7188-321.

Zemanek, Alicja 2000d: Wtadystaw Szafer (1886-1970). Botanik, fitogeograf, paleobotanik. [W:] Zemanek, Alicja (red.): Złota Ksiega Wydziału Biologii i Nauk o Ziemi. Uniwersytet Jagiellonski. Cześć I: Biografie uczonych. Kraków: Wydawnictwo Naukowe DWN. ISBN 83-7188-321.

Zemanek, Alicja 2019: Mistrz i uczeń - Marian Raciborski (1863-1917) i Władysław Szafer (1886-1970) - współtwórcy ochrony przyrody w Polsce. Roczniki Bieszczadzkie, T. 27, ss. 127-150. 